\title{
Gasification of Municipal Solid Waste for Power Generation in Brazil, a Review of Available Technologies and Their Environmental Benefits
}

Diego Mauricio Yepes Maya ${ }^{1}$, Angie Lizeth Espinosa Sarmiento ${ }^{1,2}$, Cristina Aparecida Vilas Bôas de Sales Oliveira $^{1}$, Electo Eduardo Silva Lora ${ }^{1}$ and RubenildoVieira Andrade ${ }^{1}$

1. Excellence Group in Thermal Power and Distributed Generation, Institute of Mechanical Engineering, Federal University of Itajubá, Av. BPS 1303, Itajubá, MG, CEP 37500-903, Brazil

2. Federal Center of Technological Education of Rio de Janeiro Celso Suckow da Fonseca, CEFET-RJ Areal Street, 522, Angra dos Reis, RJ, CEP 23953-030, Brazil

\begin{abstract}
This article reviews the literature on thermochemical processing of municipal solid waste as the final disposal in Brazil, explores recent publications in the field of solid waste generated, its origin, characteristics and removal mechanisms currently employed, in the same way , available technologies for the thermochemical treatment of MSW with an emphasis on gasification and clean technology are evaluated, highlighting the current technical and reported in the literature in order to identify indicators of efficiency and flexibility of the technology. From the review it is concluded that gasification is a technically feasible option for the thermochemical conversion of municipal solid waste and subsequent power generation, besides being a technology that meets the applicable emission limits. Some of the main advantages of gasification of municipal solid waste are: (a) the sharp reduction in the waste mass (about 70-80\%) and volume (approximately 80-90\%); (b) the drastic reduction in land use, 1:3000; (c) destruction of organic pollutants and other halogenated hydrocarbons; (d) concentration and immobilisation of inorganic contaminants so that they can be used effectively and safely removed; (e) use recyclables, such as ferrous metals, ferrous ash and slag materials; (f) reducing emissions of greenhouse gases by anaerobic decomposition of organic waste and (g) power generation.
\end{abstract}

Key words: MSW, waste to energy, gasification, thermo-chemical conversion, environmental advantage.

\section{Introduction}

Brazil, the sixth largest economy in the world, with over 190 million people today faces two challenges in energy supply: firstly, the need for new alternative energy sources and secondly, proper disposal of MSW (municipal solid waste); this is the generic name for any type of domestic waste routinely generated. According to the Brazilian Technical Standards Agency: "MSW are food waste, plastic bags, bottles, papers in general, clothes, pruning debris, remains of fairs such as: fruits, vegetables in general, and other materials organic and non-organic." Until the enactment of the

Corrresponding author: Diego Mauricio Yepes Maya, PhD, research field: mechanical engineering, researcher in gasification and WTE treatments.
National Solid Waste Policy [1], the MSW does not include hospital, industrial, hazardous or radioactive wastes according to ABNT, 2004 [2]. In Brazil, the MSW amount generated is approximately 200,000 tons per day [3], its (17.7\%) has as final destination open dumps, landfills (58.1\%) and controlled landfills (24.2\%), and the Southeast, accounting for nearly half of this total [4]. The objective of this paper is to review the different thermochemical treatments to eliminate MSW as well as the energy that is generated from them and demonstrate the environmental benefits reported in the literature.

\section{MSW Availability and Composition Estimation}

The MSW generation is product of the each society 
consumption habits, some authors still determine a system waste generation based on the number of habitants, a small town, less than 3,000 inhabitants, generates an average $0.50 \mathrm{~kg} /$ person/day, and larger cities, up to 5 million people can generate up to $1.0 \mathrm{~kg}$ /person/day [5]. In Brazil 2000, were generated on average 186,036 tons of MSW/day, and there was an increase of 31\% from 2000 to 2008; most of the MSW generated in Brazil is destined to landfill followed by the provision which will open dumps and landfills. According to Codignole 2013: The municipalities MSW disposal situation, only $16.82 \%$ have waste treatment, $17.86 \%$ have selective collection of recyclable waste and $82.39 \%$ waste are collected directly in the soil [2].

In accordance with Brazilian legislation [1] and others [2], the municipal solid waste generation sources are classified into three: a) domestic residence: Paper, plastic, clothing, leftover food, cans and bottles, packaging food, pruning of trees and debris from gardens; b) In commercial establishments (restaurants, offices, shops in general): Scrap paper, food scraps d, cartons, plastics, remains of gardens; c) In government offices (hospitals, prisons, schools, libraries): Paper, plastic, food scraps, garden scraps, waste classroom [5].

According to research compiled by INTOSAI and Cointreau, 2006, the MSW composition varies depending on whether is a developing country, a developed country or a sub region developed, in the case of organic waste, it will be superior presence in underdeveloped countries like almost 85\% compared to developed countries reaching only $30 \%$ in most of cases. The developed countries produce more paper, plastic, glass, metal and waste electrical equipment than countries less developed; these kinds of residues on average are over $60 \%$ for developed countries, while in developing countries are less than $20 \%$ [6, 7].

\section{Potential of MSW for Energy Generation}

The basic characteristics of municipal solid waste are usually heterogeneous, there are approaches based on separately assess of the most representative factions, as shown by some authors [2, 8-10]. However, due to the fuel quality is necessary to know about MSW availability and their actual amount on a dry basis. In the Brazilian case, the volume collection data were taken from surveys conducted on data basis from the Brazilian Institute of Geography and Statistics [11-14], in the MSW case and other relevant urban cleaning items, hit a universe of 400 municipalities surveyed as shown in Table 1.

As a result of this research is published in 2012 the Brazilian Atlas of MSW which in the results were as follows: in 2011 were generated about 198 tons per day of municipal solid waste in Brazil, which equates to about 62 million tons per year. Of the total waste generated, $90 \%$ are listed. Waste collected in 2011, $58 \%$ were destined for landfills, $24 \%$ to controlled landfills and dumps $17 \%$. This implies that there are approximately 75,000 tons daily with inadequate allocation. According to the data available for 2011, the Southeast region has 97,000 tons of MSW per day. The second region with the largest generation of municipal waste is the Northeast region, where they are generated daily about 50 tons of waste, representing $25 \%$ of the total. The South, Midwest and Northeast regions generate between $7 \%$ and $10 \%$ each [13]. Evaluating a material as a possible energy carrier is necessary to establish the organic compounds, that is why the next and final analyses are employed, moreover, it should be evaluated the upper and lower calorific value. All of them together form the foundation for the analysis of combustion or gasification processes basis

Table 1 Municipalities searches by regions for MSW [12].

\begin{tabular}{lc}
\hline Region & Number of municipalities surveyed \\
\hline North & 50 \\
Northeast & 123 \\
Midwest & 32 \\
Southeast & 132 \\
South & 63 \\
Total & 400 \\
\hline
\end{tabular}



Technologies and Their Environmental Benefits

Table 2 Elemental analysis of MSW and biomass.

\begin{tabular}{|c|c|c|c|c|}
\hline Constituent & Unit & $\mathrm{a}$ & b & C \\
\hline $\mathrm{C}$ & $\%$ & 37.42 & 49.06 & 46.78 \\
\hline $\mathrm{H}$ & $\%$ & 5.14 & 6.62 & 5.92 \\
\hline $\mathrm{O}$ & $\%$ & 29.91 & 37.55 & 45.55 \\
\hline $\mathrm{N}$ & $\%$ & 1.19 & 1.68 & 0.32 \\
\hline S & $\%$ & 0.13 & 0.2 & 0.09 \\
\hline $\mathrm{Cl}$ & $\%$ & 0.66 & 0.47 & - \\
\hline Ash & $\%$ & 25.56 & 18.16 & 1.34 \\
\hline Moisture & $\%$ & 24.1 & 28.29 & 12.23 \\
\hline LHV & MJ/dry kg & 14.36 & - & 18.06 \\
\hline HHV & $\mathrm{MJ} / \mathrm{kg}$ & 15.48 & 20.23 & - \\
\hline
\end{tabular}

a: São Paulo Br [2], b: México, DF, Mx [16], c: Eucalyptus [17].

[15]. On the case of MSW generated in Brazil, Table 2 shows a result example of a MSW mixture elemental composition in a typical Brazilian city, in a Latin American city and residual biomass.

\section{Technologies for MSW Thermochemical Conversion into Energy}

Thermal waste treatment is only one part of an integrated waste management. The heat treatment can play a number of important functions in an integrated system of waste management. The heat treatment may: (a) reduce the volume of waste, thus preserving landfill space (heat treatment does not replace the need for landfills as several waste disposal still need) [13]; (b) Allow the recovery of energy from solid waste stream unwilling landfill in Refs. [12, 13]; (c) allow the minerals and chemicals recovery from the solid waste stream, which can be reused or recycled; (d) destroying a variety of contaminants that may be present in the waste stream [10, 18]; (e) Can often reduce the need for excessive handling of waste.

In most jurisdictions, the thermal waste treatment is applied to manage the waste flow remaining after diversion of source separated by recyclables and organic materials [10]. The MSW thermal treatment has a number of technologies to extract energy from waste, reducing its volume and making the remaining fraction mainly inert [19]. These technologies can be generally grouped into two main categories: conventional and advanced combustion heat treatment. Conventional combustion technologies include incineration and burning mass of fluidized bed incineration, among others. Incineration is the most common type of technology used worldwide. Incineration is a process of waste thermal destruction at high temperatures around $900-1,200{ }^{\circ} \mathrm{C}$ with time controlled residence, the process is done through a thermal decomposition via oxidation at high temperature, where a plot organic the waste is converted into gas and another portion is converted into a solid [19]. This practice helps reduce the volume, weight and hazardous materials intended for this treatment [2].

The advanced technologies of heat treatment include gasification, pyrolysis and plasma gasification. These technologies tend to be less proven on a commercial scale and involve more complex technological processes [18, 20]. Gasification is the heating of organic waste (MSW) to produce a fuel gas (syngas), which consists of a mixture of mainly $\mathrm{H}_{2}$ and $\mathrm{CO}$, along with minor amounts of $\mathrm{CH}_{4}, \mathrm{~N}_{2}, \mathrm{CO}_{2}$ and $\mathrm{H}_{2} \mathrm{O}$. The synthesis gas produced can then be used on site or off site or a second stage of combustion heat or electricity to generate heat; gasifiers are primarily designed to produce useful syngas. The electrical efficiency of synthesis gas in the steam turbine is $15-24 \%, 20-30 \%$, in gas turbines and combustion in $14-26 \%$ engines. There are three main gasification technologies that can be used to treat waste materials, including fixed bed, fluidized bed gasification and high temperature types [10].

Gasification has been used for over 100 years in the fuels and chemicals production [21], but with little success due to the availability of fossil fuels and other forms of power generation, as well as the insufficient technological development. During the Second World War were built around a million gasifiers for use in the civilian sector, the military sector as in all gasoline used. From '80's was renewed worldwide interest in the 
research, development and construction of gasification facilities for demonstration and commercial application, particularly in the processes of biomass gasification due to the decrease of fossil fuel in the world and the increase in global warming [21].

Pyrolysis is a process for thermochemical degradation that occurs when heat is applied to a substance or material, in total absence of oxidant. In this case, pyrolysis is an endothermic process that needs an external source of energy (heat) for its development. This process allows the transformation of waste into three fractions: solid, liquid and gas. The solid fraction consisting mainly of ash and carbon (depending on the temperature employed in the process), which can be used as fuel or for the manufacture of activated carbon by its subsequent activation with $\mathrm{CO}_{2}$, steam or both. The gaseous fraction is also fuel, consisting of $\mathrm{H}_{2}, \mathrm{CO}, \mathrm{CO}_{2}, \mathrm{CH}_{4}$ and other hydrocarbons. The liquid fraction is composed of a complex mixture of aromatic hydrocarbons and aliphatic oxygenated [22]. Table 3 provides a comparison of the different technologies for the thermochemical conversion of MSW energy, some different operating parameters and the observed material characteristics.

\section{Environmental Advantages of Using Gasification as a Technology for the MSW Treatment and Disposal}

The main solid urban waste gasification advantages are: (a) a mass strong reduction of residue (about 70-80\%) and volume (about 80-90\%) [18]; (b) drastic reduction in land use (it is estimated that a treatment plant WTE (waste to energy) $1 \mathrm{Mt} /$ for nearly 30 years requires less than $100,000 \mathrm{~m}^{2}$ of land, to be compared with more than $3,000,000 \mathrm{~m}^{2}$ would be required to discharge 30 million tons of MSW) [18, 23]; (c) the destruction of organic pollutants, such as halogenated hydrocarbons [19]; (d) the concentration and immobilization of inorganic contaminants so they can be used effectively and safely disposed [23]; (e) the use of recyclable materials from the waste heat, such

Table 3 Gasification technology versus incineration for MSW treatment.

\begin{tabular}{|c|c|c|}
\hline Parameter considered & Gasification technology & Incineration \\
\hline Feedstock flexibilities & $\begin{array}{l}\text { Ability to mix raw materials, such as MSW, industrial } \\
\text { waste, commercial and industrial waste, hazardous } \\
\text { waste, tires, other biomass (such as wood waste) }\end{array}$ & MSW and other waste streams common \\
\hline Main product & Synthesis gas (carbon monoxide and hydrogen) & Ash \\
\hline Other possible products & $\begin{array}{l}\text { Replacement fuel for natural gas and fuel oil. } \\
\text { Supply via alternative or combined cycle engines. } \\
\text { Power via fuel cells (future) } \\
\text { Steam process } \\
\text { Compounds of fertilizer }\end{array}$ & $\begin{array}{l}\text { Power over rankin cycle (steam cycle). } \\
\text { Process steam }\end{array}$ \\
\hline $\begin{array}{l}\text { The overall efficiency of the } \\
\text { plant }\end{array}$ & $\begin{array}{l}\text { Combined cycle process: } 1 \text { ton of municipal solid waste } \\
\text { is capable of creating } 1,000 \mathrm{kWh} \text { of energy by setting } \\
\text { combined cycle [35]. }\end{array}$ & $\begin{array}{l}\text { Steam cycle process: } 1 \text { ton of MSW } \\
\text { generates between } 500-650 \mathrm{kWh} \text { of energy } \\
\text { [35]. }\end{array}$ \\
\hline Emissions & \begin{tabular}{|l|} 
Nitrogen oxide $\left(\mathrm{NO}_{\mathrm{x}}\right):<36 \mathrm{ppm}$ \\
Sulfur dioxide $\left(\mathrm{SO}_{2}\right)<1.05 \mathrm{ppm}$ \\
Mercury $(\mathrm{Hg}):<1.4 \mathrm{ug} / \mathrm{DSCM}^{2}$ \\
\end{tabular} & $\begin{array}{l}\text { Nitrogen oxide }\left(\mathrm{NO}_{\mathrm{x}}\right): 110-205 \mathrm{ppm} \\
\text { Sulfur dioxide }\left(\mathrm{SO}_{2}\right): 26-29 \mathrm{ppm} \\
\text { Mercury }(\mathrm{Hg}): 28-80 \mathrm{mg} / \mathrm{DSCM}{ }^{2} \\
\end{array}$ \\
\hline Dioxins and furans & $\begin{array}{l}\text { Operating temperature }\left(>1,000^{\circ} \mathrm{C}\right) \text { together with an } \\
\text { atmosphere of oxygen deprivation destroys any } \\
\text { dioxins/furans which may be present in the feedstock, } \\
\text { and eliminates the potential for the creation of } \\
\text { dioxins/furans. Syngas rapid cooling by water quench } \\
\text { prevents the de novo synthesis of dioxins and furans. }\end{array}$ & $\begin{array}{l}\text { The presence of oxygen, chlorine and } \\
\text { particles creates the ideal conditions for the } \\
\text { formation of dioxins and furans. }\end{array}$ \\
\hline Other waste treatment & $\begin{array}{l}\text { Inert, non-hazardous and non-leaching slag glass salable } \\
\text { product as a construction aggregate, the majority of the } \\
\text { particles recovered during the cleaning of the synthesis } \\
\text { gas is recycled. }\end{array}$ & $\begin{array}{l}\text { Ash, volatile and hazardous waste cannot be } \\
\text { availed }\end{array}$ \\
\hline
\end{tabular}

Source: Adaptations of Refs. [20, 29, 32]. 
Table 4 Few certified emissions gasification plant waste.

\begin{tabular}{|c|c|c|c|c|c|c|}
\hline Company. plant location & $\begin{array}{l}\text { Nippon steel } \\
\text { Kasuza, Japan }\end{array}$ & $\begin{array}{l}\text { JFE/thermosele } \\
\text { ct } \\
\text { Nagasaki, Japan }\end{array}$ & $\begin{array}{l}\text { Ebara TwinRec } \\
\text { Kawaguchi, } \\
\text { Japan }\end{array}$ & $\begin{array}{l}\text { Mitsui R21 } \\
\text { Toyohashi, } \\
\text { Japan }\end{array}$ & $\begin{array}{l}\text { Energos } \\
\text { Averoy, } \\
\text { Norway }\end{array}$ & $\begin{array}{l}\text { PlascoEn. } \\
\text { Ottawa, Canada }\end{array}$ \\
\hline Gasifier type & Downdraft & Downdraft & $\begin{array}{l}\text { Circulating } \\
\text { fluidized bed }\end{array}$ & $\begin{array}{l}\text { Rotary kiln } \\
\text { gasifier }\end{array}$ & $\begin{array}{l}\text { Gasifier grate } \\
\text { movable }\end{array}$ & Plasma \\
\hline Gasifying agent & Oxygen & Oxygen & Air & Air & Air & Air \\
\hline Temprature ${ }^{\circ} \mathrm{C}$ & $900-1,200$ & $900-1,200$ & $900-1,200$ & $<900$ & $<900$ & $>1,200$ \\
\hline Capacity tons/day & 200 & 300 & 420 & 400 & 100 & 110 \\
\hline Power production MWe & 2.3 & 8 & 5.5 & 8.7 & 10.2 & - \\
\hline \multicolumn{7}{|c|}{ Emissions, mg/m³ $\left(11 \% \mathrm{O}_{2}\right)$} \\
\hline Particulate & 10.1 & $<3.4$ & $<1$ & $<0.71$ & 0.24 & 9.1 \\
\hline $\mathrm{HCl}$ & $<8.9$ & 8.3 & $<2$ & 39.9 & 3.61 & 2.2 \\
\hline $\mathrm{NO}_{\mathrm{x}}$ & 22.3 & - & 29 & 59.1 & 42 & 107 \\
\hline $\mathrm{SO}_{\mathrm{x}}$ & $<15.6$ & - & $<2.9$ & 18.5 & 19.8 & 19 \\
\hline Dioxins / furans, n-TEQ/m³ & 0.032 & 0.018 & 0.000051 & 0.0032 & 0.0008 & 0.006 \\
\hline
\end{tabular}

Source: Adaptations of Refs. [18, 23].

as ferrous and non-ferrous metals from ashes and slags; (f) reducing emissions of greenhouse gases from anaerobic decomposition of organic waste [18, 19]; (g) generating renewable energy from solid waste [18, 23-25]. For purposes of this analysis, Appendix A. shows the operation values and issue reports some stations thermochemical treatment of MSW installed. Different MSW stations treatment via gasification, and analysis of the different publications [8, 26-32] led to the search for manufacturers, that helped develop and substantiate such claims, manufacturers, especially from Asia has offered settings for today treatment of municipal solid waste through gasification.

Several authors have highlighted the advantages of gasification of municipal solid waste until now [33], the projects in the last decade are operating and can announce it. Emission reduction offers a favorable when compared against the window and incineration, Table 4 presents a comparison of the advantages it can offer the use of gasification versus incineration of municipal solid waste [26, 28, 34].

Other methodologies allow us to know the advantages of using gasification as an effective treatment for the proper management of solid waste, such as the methodology for LCA (life cycle analysis), the recent example is a study conducted in Mexico
City, it was made clear that further significant advantages from the environmental impact which is reduced emplace as a means of municipal gasification of solid waste disposal, and therefore, the power generation. The authors report improvements in reducing acidification of the air as it leaves the issue about 4 times the amount of sulfur oxides which is emitted by incineration. Likewise the reduction in eutrophication, since, by means of gasification are sent 10 times less amount of ppm $\mathrm{PO}_{4}$ respect to incineration. The greenhouse gases, perhaps the most relevant aspect of this study, the authors reported greater reductions, no gas leaks as it occurs in landfills, and when compared to the technology of incineration, gasification avoids more $400 \%$ of $\mathrm{CO}_{2}$ emissions [16].

Since the gasification process takes place in minimal oxygen amounts, the formation of dioxins is less than combustion. Emission of dioxins by this process is $0.2 \mathrm{e}^{-10} \mathrm{~g} / \mathrm{m}^{3}$ produced gas while burning the biogas produced in landfills through torches is $1.8 \mathrm{e}^{-7}$ $\mathrm{g} / \mathrm{m}^{3}$ biogas[16, 34].

\section{Conclusions}

The gasification process is an intermediate for the production of a fuel gas which can be used in a wide variety of applications. It is also evident that, although the fuel and chemicals production from MSW 
gasification is possible, and it is likely the true goal for the near future. The most prevalent method is the synthesis gas use for energy production is already thermal or electrical.

Brazil has an interesting potential for energy from municipal solid waste, collection reaches almost $80 \%$, which translates to 243,707 ton/Day, considering the process efficiency in the literature and manufacturers, the potential energy from MSW gasification is about $180 \mathrm{MW}_{\mathrm{t}} /$ day.

Gasification could be proposed as a viable alternative for the treatment of municipal solid waste with energy recovery, can be a solution to the problem through the use of land used for landfill, and compared with the practice of incineration has lower emissions. However, it still faces some technical and economic challenges, mainly related to the highly heterogeneous MSW nature, some little-known experiences of the world using this technology, and costs, which are now high compared to the current incineration technologies.

\section{Acknowledgments}

The authors express their recognitions to the Committee on Coordination of Improvements in Higher Education (CAPES), the National Research Council of Brazil (CNPq) and the Foundation for the Support of Researches of the State of Minas Gerais (FAPEMIG) for financial support. Then to the Excellence Center in Thermoelectric Generation and Distributed (NEST), the Mechanical Engineering Institute and the Federal University of Itajubá (UNIFEI) mechanical engineering post graduate program.

\section{References}

[1] Ediçoes, C. 2012. Ed., Política Nacional de Resíduos SólidoS, 2nd ed. Brasilia.

[2] Codignole, F. 2013. "Project and Technical-Economic Evaluation of Gasification Plants for Urban Waste for Distributed Generation of Electricity.” Federal University of Itajubá.

[3] Salomão, A. 2010. “World Bank Examines Garbage in Brazil.” Exame.com, [Online]. Available: http://exame.abril.com.br/blogs/aqui-no-brasil/2010/10/0 4/banco-mundial-faz-estudo-sobre-o-lixo-no-brasil/.

[Accessed: 15-May-2013].

[4] "Energia Obtida A Partir do Lixo." Fontes de energia, 2013. [Online]. Available: http://fontes-energeticas.blogspot.com.br/p/lixo.html.

[Accessed: 15-May-2013].

[5] Feam, Dped, and Gemuc, Aproveitamento Energético de Resíduos Sólidos Urbanos: Guia. Belo Horizonte, 2012.

[6] Shonhiwa, C. 2013. An Assessment of Biomass Residue Sustainably Available for Thermochemical Conversion to Energy in Zimbabwe, vol. 52. Elsevier Ltd. [7] Cointreau, S. 2006. "Occupational and Envireomental Health Issues of Solid Waste Management." Urban Pap. 57.

[8] Yamada, S., Shimizu, M., and Miyoshi, F. 2004. "Thermoselect Waste Gasification and Reforming Process.” JFE Tech. Rep. 3 (3): 21-6.

[9] Woolcock, P. J., and Brown, R. C. 2013. "A Review of Cleaning Technologies for Biomass-derived Syngas.” Biomass and Bioenergy 52: 54-84.

[10] Stantec. 2011. "Waste to Energy a Technical Review of Municipal.” Bumaby, BC.

[11] Abrelpe and Plastivida. 2013. "Caderno Informativo: Recuperacçao Energética.” São Paulo.

[12] Abrelpe, Panorama Dos resíDuos Sóldos no Brasil, 2011. São Paulo: abrelpe.

[13] Abrelpe. 2013 “Atlas Brasileiro de Emissões de GEE e Potencial Energético na Destinaçao de Resíduos Sólidos,” São Paulo.

[14] Abrelpe. 2008 "Panorama Dos Residuos sólidos no Brasil.”.

[15] Basu, P. 2013. Biomass Gasification, Pyrolysis and Torrefaction: Practical Design and Theory.

[16] Lopez, J. B. P. 2010. "Evaluación de Los Impactos Ambientales Generados por la Gasificación y la Incineración como Tratamientos de Gestión de Residuos Sólidos para la Ciudad de México.” Instituto tecnológico y de Estudios Superiores de Monterrey.

[17] Giraldo, R. S. Y. 2013. “Avaliação de um Sistema de Limpeza integrado a um Conjunto Gaseificador de Biomassa/Célula SOFC." Universidade Federal de Itajubá.

[18] Arena, U. 2012. "Process and Technological Aspects of Municipal Solid Waste Gasification. A Review.” Waste Manag 32 (4): 625-39.

[19] Kothari, R., Tyagi, V., and Pathak, A. 2010. "Waste-to-energy: A Way from Renewable Energy Sources to Sustainable Development.” Renew. Sustain. Energy 14 (9): 3164-70. 
[20] Arena, U. 2012. "Department of Environmental Sciences-Second University of Naples of Wastes WtE processes.”

[21] Bridgwater, V., Toft, J., and Brammer, J. G. 2002. A Techno-Economic Comparison of Power Production by Biomass Fast Pyrolysis with Gasification and Combustion, vol. 6, no. 3.

[22] Basu, P. 2010. Biomass Gasification and Pyrolysis. Burlington, MA: Elsevier Inc..

[23] Galeno, G., Minutillo, M., and Perna, A. 2011. "From Waste to Electricity Through IPGFC (Integrated Plasma Gasification/Fuel Cell) System,” Int. J. Hydrogen Energy 36 (2): 1692-701.

[24] Epe-Empresa, D. 2008. "Aproveitamento Energético Dos resíDuos sóLidos Urbanos de Campo Grande, MS.” Rio Janeiro EPE.

[25] Rebitanim, N. Z., Karim, G. W. A., Rebitanim, N. A., and Amran, M. S. M. 2013. "Potential Applications of Wastes from Energy Generation Particularly Biochar in Malaysia.” Renew. Sustain. Energy Rev. 21: 694-702.

[26] "Waste Treatment: Fluidized Bed Gasification and Melting Furnace-Kobelco Eco-Solutions Co., Ltd.” [Online]. Available: http://www.kobelco-eco.co.jp/english/product/haikibutus hori/ryudo_q3.html. [Accessed: 03-Jun-2013].

[27] "Mitsui Recycling, Pyrolysisgasification \& Melting Process.” [Online]. Available: http://www.ieabcc.nl/workshops/Tokyo_Joint_Meeting/0 2_Mitsui.pdf. [Accessed: 03-Jun-2013].

[28] “News Releases | 2013 - MITSUI \& CO., LTD.” [Online].

Available: http://www.mitsui.com/jp/en/release/2013/index.html.

[Accessed: 03-Jun-2013].

[29] Strobino, F., Prato, A., Ventura, D., and Damonte, M. 2012. "Energy Recovery From Msw Treatment by Gasification and Melting Technology.” ecos2012.org, 1-15.

[30] "JFE Steel Corporation - Products and Services." [Online]. Available:

http://www.jfe-steel.co.jp/en/products/index.html.

[Accessed: 03-Jun-2013].

[31] "Energy-from-Waste Plants Products Hitachi Zosen Corporation.” [Online]. Available: http://www.hitachizosen.co.jp/english/products/products0 01.html. [Accessed: 03-Jun-2013].

[32] Tanigaki, N., Manako, K., and Osada, M. 2012. "Co-gasification of Municipal Solid Waste and Material Recovery in a Large-scale Gasification and Melting System.” Waste Manag. 32 (4): 667-75.

[33] "A Review of State-of-the-art for WtE Technologies in Relation to the Study just Completed for the DEPARTMENT of Environment \& Conservation, Government of Western Australia.” [Online]. Available: http://www.wasteauthority.wa.gov.au/media/files/docume nts/WtE_presentation_Dec_2012.pdf. [Accessed: 03-Jun-2013].

[34] Schilli, J. W. 2004. "Using Gasification to Process Municipal Solid Waste.” HDR Innov.12 (4).

[35] “The Plasco Advantage." [Online]. Available: http://www.plascoenergygroup.com/our-solution/the-plas co-advantage/. [Accessed: 03-Jun-2013]. 